\title{
Characterization of Bacillus licheniformis KJ-9 Isolated from Soil
}

\author{
Dong-Cheol Seo ${ }^{1}$, Jeong-Ae Ko, Sang-Won Gal and Sang-Won Lee* \\ Dept. of Microbiological Engineering Jinju National University, Jinju 660-758, Korea \\ ${ }^{1}$ Institute of Agriculture and Life Sciences, Gyeongsang National University, Jinju, 660-701, Korea
}

Received December 15, 2009 /Accepted December 18, 2009

\begin{abstract}
In order to produce high-quality fermenting composts, a microorganism was isolated from the natural world. The bacterium has not only in high enzyme activities but also had good antimicrobial activities against phytopathogenic microorganisms. Its cultivating characteristics were then investigated. Bacterium KJ-9, which contains high CMCase, protease and chitinase activities and excellent antimicrobial activities against phytopathogenic microorganisms, was separated from leaf mold and identified as Bacillus licheniformis by two methods: Bergey's Manual of Systematic Bacteriology and API 50 CHL Carbohydrate Test Kit (Bio Merieux, France) using an ATB (Automated Identification) computer system (Bio Merieux, France). Optimal medium for cultivation of B. licheniformis was $2 \%$ soluble starch as a carbon source, $0.5 \%$ yeast extract as a nitrogen source and $0.05 \% \mathrm{MgSO}_{4} \cdot 7 \mathrm{H}_{2} \mathrm{O}$. Optimal growth conditions of $\mathrm{pH}$, temperature and shake speed were $\mathrm{pH} 7.0,50^{\circ} \mathrm{C}$ and $180 \mathrm{rpm}$, respectively. Culture broth of $B$. licheniformis KJ-9 cultured for 36 60 hr was effective in fungicidal activities against plant pathogens including Botrytis cinerea, Corynespora cassicola, Fusarium oxysporum, and Rhizoctonia solani.
\end{abstract}

Key words : Antimicrobial activity, Bacillus licheniformis, phytopathogenic microorganisms, optimal medium

\section{서 론}

최근 환경 문제가 세계적인 관심사로 떠오르고 환경오염으 로 인한 피해사례가 급증하면서 농업환경 문제점의 중요성이 크게 부각되고 있다. 농업환경에 있어서는 농약과 화학비료의 과다사용으로 인하여 농업 생태계가 파괴되고 있으며, 식물병 원균들의 저항성 획득, 수질오염, 토양의 산성화, 잔류농약의 문제 및 인축의 농약 중독 등 그 피해가 나날이 증가하고 있는 실정이다[5]. 특히 소비자들의 건강 지향적인 인식으로 유기농 및 친환경 농산물을 선호하는 경향이 있기 때문에 농업분야에 서도 지속가능한 친환경농업의 필요성이 급증하고 있으며, 이 를 위한 대체방법의 하나로 토양내의 길항미생물에 의한 식물 병원성균의 발병억제 방법인 생물학적 방제법이 활발히 연구 되고 있다[5,22].

여러 가지 식물병원성 진균에 대한 길항균주를 이용한 생태 학적 생물방제방법에는 첫째는 진균 외막가수분해효소인 chitinase, $\beta-1,3$-glucanase와 같은 효소에 의해 식물병원균의 세 포벽을 분해시키는 용균작용[14], 둘째는 Streptomyces griseus [4], Streptomyces blastmyces [24], Penicillium nigricans [3], Bacillus subtilis [17] 및 Pseudomonas sp. [2] 등이 생산하는 항진 균성 항생물질에 의해 직접 식물병원균의 생육을 저해시키는 항생작용(antibiosis), 셋째는 식물성장 촉진세균(plant growth-

*Corresponding author

Tel : +82-55-751-3394, Fax : +82-55-751-3399

E-mail : swlee@jinju.ac.kr promoting rhizobacteria, PGPR) 즉, 대부분 근권 Pesudomonas $\mathrm{sp}$.이 분비하는 철 $\left(\mathrm{Fe}^{3+}\right)$ 성분 결합물질인 siderophore에 의해 식물병원균의 생육을 저해하는 경쟁적 길항작용(compective antagonism)을 이용한 방제방법 등이 있다[19]. 이러한 경쟁적 길항작용은 토양 전염병을 감소시키며, 기주식물의 근권 정착 능력을 촉진함으로서 작물의 성장을 양호하게 하여 수확량을 증대 할 수 있는 효과적인 생물학적 방제 방법이라 할 수 있다 [5]. Mitchell [18] 등은 1944년 의료용으로 발견된 streptomy$\operatorname{cin}$ 이 식물병원균에 유효하다는 보고를 하였으며 이를 토대로 하여 phytomycine, agristreptomycin agrimycin이 개발되어 실용화됨에 따라 길항 물질이 농업용 살균제로 등장하였다. 이것을 계기로 항생물질이 농업용 살균제로 사용되기 시작하 였다[12].

따라서 본 연구에서는 식물병해에 효과적이면서 톱밥의 발 효를 효율적으로 진행시켜 고품질의 톱밥 발효퇴비를 생산할 목적으로 cellulase 및 chitinase 등의 효소분비력이 우수함과 동시에 여러 종류의 식물병원성균에 대하여 항균활성이 높은 토양미생물을 자연계로부터 순수분리하여 그 배양학적 특성 을 조사하였다.

\section{재료 및 방법}

\section{공시균주}

임의로 채취한 약 300여 점의 부식토 및 부엽토 등으로부터 carboxy methyl cellulase (CMCase), protease 및 chitinase활 
성이 높고, 식물병 원성균주에 대하여 생육억제력이 강한 균주 를 최종 순수분리하여 공시균주로 사용하였다. 항균활성 측정 을 위한 식물병원성균주는 농업진흥청 응용미생물과에서 분 양 받은 잿빛 곰팡이병을 유발하는 Botrytis cinerea, 잎마름병 의 원인균인 Corynespora cassicola, 시들음병을 유발하는 Fusarium oxysporum, 잘록병의 원인균인 Rhizoctonia solani의 균주를 사용하였다.

\section{사용배지}

항균미생물의 분리용 배지로는 carboxy methyl cellulose (CMC)가 함유된 CY배지(CMC 1\%, yeast extract $1 \%, \mathrm{KH}_{2} \mathrm{PO}_{4}$ $0.1 \%,\left(\mathrm{NH}_{4}\right)_{2} \mathrm{SO}_{4} 0.1 \%, \mathrm{MgSO}_{4} \cdot 7 \mathrm{H}_{2} \mathrm{O} 0.05 \%$ 및 agar $\left.2 \%\right)$ 를 사용하였고, 식물 병원성균주의 생육 및 보존을 위한 배지는 $\mathrm{PDA}$ (Difco) 평판배지를 사용하였다. 분리균주의 최적배지 검 토를 위한 최소배지는 M9 minimal medium [25] (glucose $2 \%$, $\mathrm{MgSO}_{4} \cdot 7 \mathrm{H}_{2} \mathrm{O} 0.2 \% \mathrm{Na}_{2} \mathrm{HPO}_{4} \cdot 7 \mathrm{H}_{2} \mathrm{O} 6.4 \%, \mathrm{KH}_{2} \mathrm{PO}_{4} 1.5 \%$, $\mathrm{NH}_{4} \mathrm{Cl} 0.5 \%$ 및 $\mathrm{NaCl} 0.02 \%$ )를 사용하였다.

\section{항균미생물의 선정 및 동정}

채취한 시료 $1 \mathrm{~g}$ 을 멸균 생리식염수 $9 \mathrm{ml}$ 에 희석하여 그 시료용액 $0.1 \mathrm{ml}$ 를 CY평판배지에 직접 도말한 다음 $50^{\circ} \mathrm{C}$ 에서 24시간 배양한 후 $0.1 \%$ congo red를 뿌려 나타나는 clear zone 의 크기로 1 차 선별하였다[13]. 1차 선별한 미생물은 액체 배지 상에서 진탕배양한 후 CMCase, protease 및 chitinase 활성을 측정하여 3 종류의 효소활성이 동시에 높은 균주를 2 차 선별한 다음 PDA 평판 배지 상에서 식물 병원성균주에 대한 항균활 성이 높은 군주를 최종 분리균주로 선정하였다. 분리균주의 동정을 위한 형태학적 및 생화학적특성을 검토하여 Bergey's Manual of Systematic Bacteriology [23] 및 Bergey's mannual of determinative bacteriology. 9th [7]에 준하여 1차 동정하였 다. 당 발효실험은 API $50 \mathrm{CHL}$ carbohydrate test kit (Bio Merieux, France)를 사용하여 Nutrient broth 배지에 24시간 배양하면서 배양액의 색도변화 결과를 ATB identification computer system (Bio Merieux, France)에 입력하여 조사하 고, $16 \mathrm{~S} \mathrm{rDNA}$ 유전자 분석을 행하여 동정하였다.

\section{효소활성}

분리균주의 효소활성 측정은 $500 \mathrm{ml}$ 삼각플라스크에 $\mathrm{CY}$ 배 지 $200 \mathrm{ml}$ 를 넣고 분리균주의 전배양액을 $2 \mathrm{ml}$ 접종하여 $50^{\circ} \mathrm{C}$ 에서 24 시간 배양한 다음, 배양액을 $8,000 \times g$ 에서 10 분 동안 원심분리하여 얻은 상징액을 조효소액으로 사용하였다. CMCase활성은 조효소액 $0.25 \mathrm{ml}$ 에 $1 \% \mathrm{CMC} 0.75 \mathrm{ml}$ 을 혼합 하여 $50^{\circ} \mathrm{C}$ 의 항온수조에서 10 분간 반응시킨 다음, 3,5 -dinitrosalysilic acid (DNS)법[16]으로 측정하여 CMCase 1unit는 1 분 동안에 $1 \mu \mathrm{g}$ 의 D-glucose를 생산하는 효소의 양으로 나타 내었다. Protease 활성은 Anson 등[1]의 방법에 준하여 측정하
였으며, protease 1 unit는 조효소액 $1 \mathrm{ml}$ 가 1 분간 $1 \mu \mathrm{g}$ 의 trosine을 생성하는 효소의 양으로 나타내었다. Chitinase의 활 성은 $0.05 \mathrm{M}$ phosphate buffer (pH 7.0)에 현탁시킨 colloidal chitin을 효소반응 기질로 사용하여 DNS법에 따라 측정하였 다. Chitinase 1 unit는 시간당 colloidal chitin으로부터 $1 \mu \mathrm{M}$ N-acetyl-D-glucosamine을 생성하는 효소량으로 나타내었다.

\section{항균활성}

항균활성 측정은 PDA평판배지 중앙에 corker borer NO.5 (직경 $7 \mathrm{~mm}$ )를 이용하여 식물 병원성균주를 블록형태로 접종 한 다음 $25^{\circ} \mathrm{C}$ 의 항온기에서 접종한 곰팡이의 균사가 평판배지 의 $1 / 3$ 정도를 덮을 때까지 배양하였다. 이때 성장하는 곰팡이 균사의 끝으로부터 $1 \mathrm{~cm}$ 정도 떨어진 지점에 corker borer $\mathrm{NO} .5$ (직경 $7 \mathrm{~mm}$ )를 이용하여 평판배지 상에 구멍을 똟은 다음 순수분리한 항균미생물의 배양용액을 $0.2 \mu \mathrm{m}$ membrane filter로 여과한 시료용액 $150 \mu \mathrm{l}$ 접종한 후 $25^{\circ} \mathrm{C}$ 에서 $24 \sim 72$ 시 간 대치배양하면서 식물 병원성균주의 균사성장 억제정도 (inhibition zone)를 관찰하였다[21].

\section{최적 배지성분}

분리균주의 최적배지 성분은 $\mathrm{M} 9$ minimal medium [20]를 기준으로 탄소원은 mannitol, fructose, glucose, D-sorbitol, cellobiose, sorbose, xylose, galactose, maltose, soluble starch, arabinose, lactose 및 raffinose를 각각 $1 \%$ 농도로 첨가하고 분리균주의 전 배양액을 $2 \%$ 씩 접종한 후 $50^{\circ} \mathrm{C}$ 에서 20 시간, $180 \mathrm{rpm}$ 으로 진탕 배양한 다음 배양액의 탁도를 $660 \mathrm{~nm}$ 에서 측정하였다. 탄소원 첨가농도의 영향은 선정된 탄소원을 0 , $0.5,1.0,1.5,2.0,2.5,3.0,3.5,4.0$ 및 5.0\% 씩 각각 첨가하여 동일조건에서 검토하였다. 그리고 질소원은 yeast extract, malt extract, beef extract, $\mathrm{NaNO}_{3}, \mathrm{NH}_{4} \mathrm{NO}_{3}$, L-asparagine, peptone, $\left(\mathrm{NH}_{4}\right)_{2} \mathrm{HPO}_{4}$ 및 $\mathrm{NH}_{4} \mathrm{Cl}$ 등을 각각 $0.5 \%$ 씩 첨가한 후 탄소원의 검토 방법과 동일하게 행하였다. 무기염은 $\mathrm{CoCl}_{2}$. $6 \mathrm{H}_{2} \mathrm{O}, \mathrm{CaCl}_{2}, \mathrm{NaCl}, \mathrm{ZnCl}_{2}, \mathrm{FeSO}_{4} \cdot 7 \mathrm{H}_{2} \mathrm{O}, \mathrm{AgNO}_{3}, \mathrm{HgCl}_{2}$, $\mathrm{MgCl}_{2} \cdot 6 \mathrm{H} 2 \mathrm{O}, \mathrm{K}_{2} \mathrm{HPO}_{4}, \mathrm{ZnSO}_{4} \cdot 7 \mathrm{H}_{2} \mathrm{O}$ 및 $\mathrm{MgSO}_{4} \cdot 7 \mathrm{H}_{2} \mathrm{O}$ 등 을 각각 $0.05 \%$ 씩 첨가하여 탄소원의 검토방법과 동일하게 행 하였다.

\section{최적배양조건}

분리균주의 최적배양조건은 $500 \mathrm{ml}$ 삼각플라스크에 액체 배지를 $200 \mathrm{ml}$ 첨가한 다음 분리균주의 전 배양액을 $2.0 \%$ 씩 접종하여 검토하였다. 최적배양온도는 배양온도를 $25 \sim 65^{\circ} \mathrm{C}$ 의 범위로 변화시키면서 $180 \mathrm{rpm}$ 에서 20시간 배양한 후 660 $\mathrm{nm}$ 에서 배양액의 흡광도를 측정하였다. 배지의 초기 $\mathrm{pH}$ 는 $0.1 \mathrm{~N} \mathrm{HCl}$ 과 $0.1 \mathrm{~N} \mathrm{NaOH}$ 를 첨가하여 초기 $\mathrm{pH}$ 를 $4 \sim 10$ 범위로 조절한 다음 행하였고, 진탕속도의 영향은 최적배지의 초기 $\mathrm{pH}$ 를 7.0으로 조절한 후 진탕 속도를 100, 140, 180, 220 및 
$260 \mathrm{rpm}$ 으로 변화시키면서 $50^{\circ} \mathrm{C}$ 에서 20 시간 배양하여 배양액 의 흡광도를 $660 \mathrm{~nm}$ 에서 측정하였다.

\section{배양시간에 따른 항균물질의 생산}

배양시간이 항균물질의 생산에 미치는 영향은 최적배지에 분리균주의 전 배양액 $2 \%$ 를 접종하고 최적 배양 조건으로 배 양하면서 $24,36,48$ 및 60 시간째에 시료를 채취하여 8,000× $g$, 20분간 원심분리하여 얻어진 상징액을 $0.45 \mu \mathrm{m}$ membrane filter로 무균 여과한 다음 식물 병원성균주에 대한 항균활성을 측정하였다.

\section{결과 및 고찰}

\section{미생물의 순수분리}

톱밥을 주원료로 제조되고 있는 퇴비의 효율적인 발효 균주 를 탐색하기 위하여 carboxy methyl cellulase (CMCase)가 함 유된 CY평판배지 상에서 clear zone의 크기가 크고, $50^{\circ} \mathrm{C}$ 의 고온에서도 생육속도가 빠른 20 여종의 미생물을 1 차 분리한 후 액체 배양하여 CMCase, protease 및 chitinase 효소활성이 비교적 높게 나타난 8 균주를 Table 1에 나타내었다. CMCase 활성은 $\mathrm{KJ}-09, \mathrm{KJ}-37, \mathrm{KJ}-33$ 균주의 순으로, protease활성은 $\mathrm{KJ}-09, \mathrm{KJ}-02, \mathrm{KJ}-50$ 균주의 순으로 그리고 chitinase활성은 $\mathrm{KJ}-9, \mathrm{KJ}-2, \mathrm{KJ}-33$ 균주의 순으로 높게 나타났다.

\section{식물병원성균주에 대한 항균활성}

2차 순수 분리한 미생물이 식물 병원성균에 대한 항균활성 을 검토하여 Fig. 1에 나타내었다. 분리한 미생물 중에서는 clear zone의 크기가 크고 효소활성이 높아도 전혀 항균활성을 나타내지 않는 미생물이 있었으며, 또한 미생물의 종류에 따 라서도 항균활성은 많은 차이를 나타내었다. 분리균주 중에서 $\mathrm{KJ}-9$ 는 잿빛 곰팡이병을 유발하는 Botrytis cinerea, 잎마름병의 원인균인 Corynespora cassicola, 시들음병을 유발하는 Fusarium oxysporum, 잘록병의 원인균인 Rhizoctonia solani의 식물병원 성 균주에 강한 항균활성을 보였다. 이상의 결과로 효소의 활

Table 1. Comparison of cellulase, protease and chitinase activities from the isolated bacteria

\begin{tabular}{cccc}
\hline \multirow{2}{*}{ Strains } & \multicolumn{3}{c}{ Enzyme activities (units/ml) } \\
\cline { 2 - 4 } & CMCase & Protease & Chitinase \\
\hline KJ-02 & 3.3 & 49.4 & 9.1 \\
KJ-07 & 3.0 & 23.1 & 3.2 \\
KJ-09 & 3.8 & 58.9 & 9.7 \\
KJ-32 & 3.0 & 40.6 & 2.2 \\
KJ-33 & 3.5 & 42.5 & 8.9 \\
KJ-37 & 3.6 & 30.7 & 3.7 \\
KJ-45 & 3.2 & 34.3 & 3.1 \\
KJ-50 & 3.4 & 45.7 & 8.4 \\
\hline
\end{tabular}
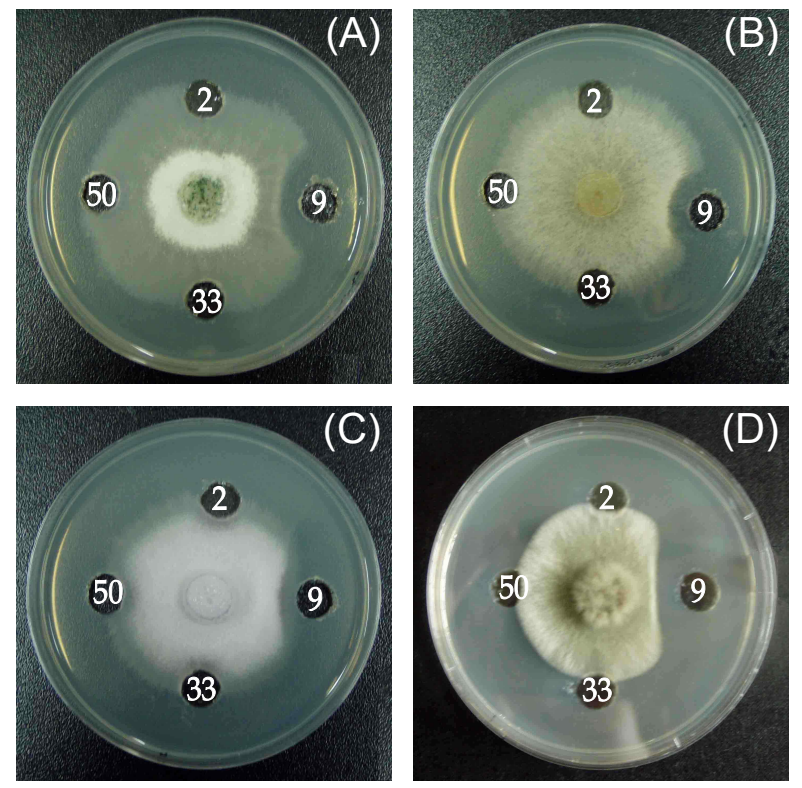

Fig. 1. Antifungal activities of culture broth of the isolated bacteria against phytopathogenic fungi. A, Botrytis cinerea, B, Rhizoctonia solani, C, Fusarium oxysorum, D, Corynespora cassicola

성이 높으면서 4 종류의 식물병원성 미생물에 대하여 강한 항 균활성을 가지고 있는 $\mathrm{KJ}-9$ 를 최종 분리균주로 선정하였다.

\section{항균미생물의 동정}

최종 선정한 항균미생물인 $\mathrm{KJ}-9$ 의 형태학적 및 생태학적 특성을 검토하여 Table 2와 3에 나타내었다. 분리한 KJ-9균주 는 Gram 양성이며 편모 및 내생포자를 가지는 간균(0.9-1.2 $\times$ 2.0-3.2 $\mu \mathrm{m})$ 으로 나타났다. 생화학적 특성은 oxidase, catalase 및 urease반응은 양성이었으나, indol 생성은 음성이었다. 이러한 결과를 토대로 Bergey's Manual of Systematic Bacteriology [23] 및 Bergey's Manual of Determinative Bacteriology [7]에 준하여 동정한 결과 Bacillus 속(genus)인 것으로 추정되었으며 Table 3의 API kit(API, France)를 사용 한 당 발효실험의 결과를 ATB indentification program에 입 력하여 분석하고 그리고 $16 \mathrm{~s} \mathrm{rDNA}$ 분석(Fig. 2)을 행한 결과

Table 2. Characteristics of physiological and biochemical strain KJ-9

\begin{tabular}{lclc}
\hline $\begin{array}{c}\text { Test of } \\
\text { characteristics }\end{array}$ & KJ-9 & \multicolumn{1}{c}{$\begin{array}{c}\text { Test of } \\
\text { characteristics }\end{array}$} & KJ-9 \\
\hline Gram stain & + & Spore formation & + \\
Cell type & Rod & Oxidase reaction & + \\
Size $(\mu \mathrm{m})$ & $0.9-1.2 \times 2.0-3.2$ & Catalase reaction & + \\
Motility & + & Urease reaction & + \\
Colony color & Ivory & Voges-Prostauer test & + \\
Fluorescence & - & Citrate utilization & + \\
Flagellum & + & Indol production & - \\
\hline
\end{tabular}


Table 3. Characteristics of the isolated bacterium KJ-9

\begin{tabular}{lclc}
\hline \multicolumn{1}{c}{ Substrate } & Read & \multicolumn{1}{c}{ Substrate } & Read \\
\hline Glycerol & + & Sorbitol & + \\
Erythritol & - & a-Methyl-D-Mannoside & - \\
D-Arabionse & - & a-Methyl-D-Glucoside & + \\
L-Arabinose & + & N-Acetyl-Glucosamide & - \\
Ribose & + & Amygdalin & + \\
D-xylose & + & Arbutin & + \\
L-xylose & - & Esculin & + \\
Adonitol & - & Salicin & + \\
B-methyl-D-xyloside & - & Celobiose & + \\
Galactose & - & Maltose & + \\
Glucose & + & Lactose & + \\
Fructose & + & Sucrose & + \\
Mannose & + & Trehalose & + \\
Sorbose & - & Inulin & - \\
Rhamnose & - & Melezitose & - \\
Dulcitol & - & Gelatin & + \\
Inocitol & + & Casein & + \\
Mannitol & + & Starch & + \\
\hline
\end{tabular}

+: Positive reaction, -: Negative reaction.

CAGCTANNGCGTATACATGCTAGATCGAGCGTGCACAGATGGGA GCTTGCTCCCTGATGTTAGCGGCGGACGGGTGAGTAACACGTGGGTAACC TGCCTGTAAGACTGGGATAACTCCGGGAAACCGGGGCTAATACCGGATGG TTGTTTGAACCGCATGGTTCAGACATAAAAGGTGGCTTCGGCTACCACTT ACAGATGGACCCGCGGCGCATTAGCTAGTTGGTGAGGTAACGGCTCACCA AGGCGACGATGCGTAGCCGACCTGAGAGGGTGATCGGCCACACTGGGACT GAGACACGGCCCAGACTCCTACGGGAGGCAGCAGTAGGGAATCTTCCGCA ATGGACGAAAGTCTGACGGAGCAACGCCGCGTGAGTGATGAAGGTTTTCG GATCGTAAAGCTCTGTTGTTAGGGAAGAACAAGTGCCGTTCAAATAGGGC GGCACCTTGACGGTACCTAACCAGAAAGCCACGGCTAACTACGTGCCAGC AGCCGCGGTAATACGTAGGTGGCAAGCGTTGTCCGGAATTATTGGGCGTA AAGGGCTCGCAGGCGGTTTCTTAAGTCTGATGTGAAAGCCCCCGGCTCAA CCGGGGAGGGTCATTGGAAACTGGGGAACTTGAGTGCAGAAGAGGAGAGT GGAATTCCACGTGTAGCGGTGAAATGCGTAGAGATGTGGAGGAACACCAG TGGCGAAAGCGACTCTCTGGTCTGTAACTGACGCTGAGGAGCGAAAGCGT GGGGAGCGAACAGGATTAGATACCCTGGTAGTCCACGCCGTAAACGATGA GTGCTAAGTGTTAGGGGTTTCCGCCCCTTAGTGCTGCAGCTAACGCATTA AGCACTCGCCTGGGGAGTACGGTCGCAAGACTGAACTCAAAGGAATTGAC GGGGCCCGCACAAGCGGTGGAGCATGTGGTTTANCGAGCACGCGAGACNN

Fig. 2. $16 \mathrm{~S}$ rDNA sequence of Bacillus licheniformis.

분리한 KJ-9균주는 $98 \%$ 정도 Bacillus licheniformis와 유사한 것 으로 판명되어 최종분리 선정한 균주를 Bacillus licheniformis $\mathrm{KJ}-9$ 로 명명하였다.

\section{탄소원의 영향}

탄소원의 종류가 분리한 B. licheniformis $\mathrm{KJ}-9$ 의 생육에 미치 는 영향을 검토하여 Fig. 3에 나타내었다. B. licheniformis KJ-9 은 soluble starch, glucose 및 fructose 등의 순으로 잘 이용하 였으나, lactose, raffinose 및 sorbose 등은 잘 이용하지 못하는 것으로 나타났다. 이상의 결과로 B. licheniformis KJ-9의 최적 탄소원은 soluble starch로 결정하고 그 최적 첨가농도를 검토

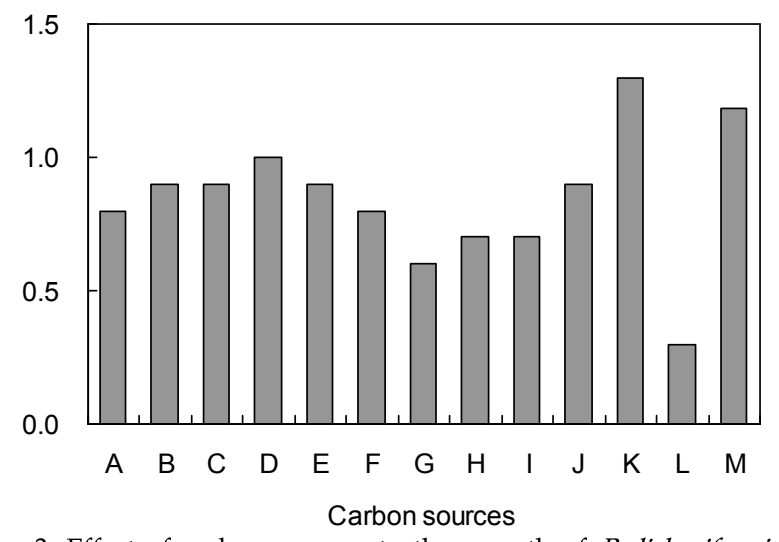

Fig. 3. Effect of carbon sources to the growth of $B$. licheniformis KJ-9. A, Mannitol; B, Xylose; C, Sorbitol; D, Fructose; E, Arabinose; F, Cellobiose; G, Raffinose; H, Galactose; I, Sorbose; J, Maltose; K, Soluble starch; L, Lactose; M, Glucose

하여 Fig. 4에 나타내었다. Soluble starch의 첨가농도를 $1.5 \%$ 까지 증가시킴에 따라 균체의 성장은 거의 직선적으로 증가하 였으나 그 이상의 농도에서는 거의 영향이 없는 것으로 나타 나 soluble starch의 최적 첨가농도는 $1.5 \%$ 로 결정하였다. Yun 등[25]은 고추역병에 항균활성을 갖는 Chryseomonas luteola 5042 를 선발하여 최적 탄소원을 검토한 결과 $0.5 \%$ $\mathrm{D}(+)$-cellobiose가 최적으로 보고하였으며, Jung 등[8]은 키토 산 분해효소를 생산하는 Baciilus sp.를 분리하여 최적 탄소원 을 검토한 결과 $0.5 \%$ xylose를 첨가하였을 때 최적이라고 보고 한 것과는 다소 상이하였다. 그리고 $\operatorname{Kim}$ [9]은 Baciilus sp.의 생육을 억제하는 방선균의 경우 xylose를 $2 \%$ 첨가했을 때 균 의 증식이 가장 우수한 것으로 보고하였다. 이상의 결과로 분 리균주에 따라 이용하는 탄소원의 종류 및 첨가농도는 다소 차이가 있는 것으로 사료된다.

\section{질소원의 영향}

질소원의 종류가 항균미생물인 B. licheniformis $\mathrm{KJ}-9$ 의 생육

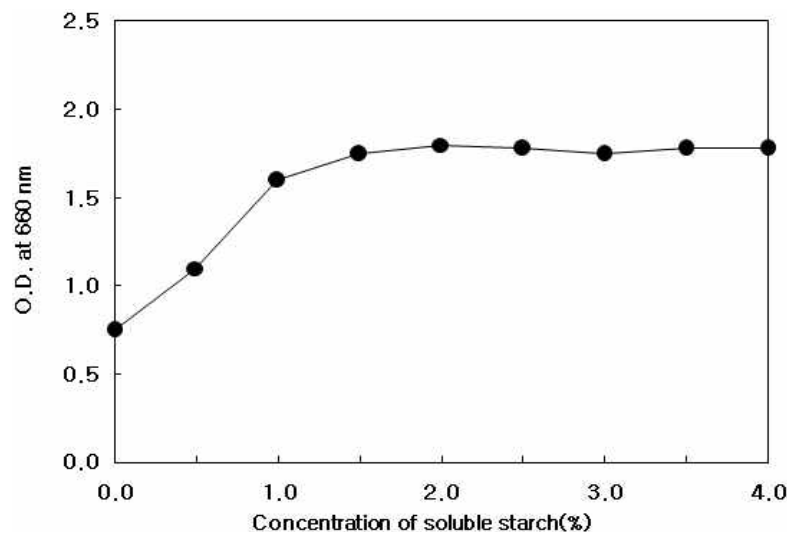

Fig. 4. Effect of concentration of soluble starch to the growth of $B$. licheniformis $\mathrm{KJ}-9$. 
에 미치는 영향을 검토하여 Fig. 5에 나타내었다. M9 minimal medium에 soluble starch를 1.5\% 첨가하고 여러 종류의 질소 원을 각각 $0.5 \%$ 씩 첨가하여 배양한 결과 $\mathrm{NH}_{4} \mathrm{NO}_{3}, \mathrm{NH}_{4} \mathrm{Cl}$, 및 $\left(\mathrm{NH}_{4}\right)_{2} \mathrm{HPO}_{4}$ 와 같은 무기질소원 보다는 yeast extract, peptone 및 beef extract와 같은 유기질소원을 잘 이용하는 것으로 나타났다. 그 중에서도 yeast extract를 첨가한 시험구에서 균 체 성장이 가장 왕성하였기 때문에 최적 질소원을 yeast extract로 결정하고, 그 첨가 농도를 검토한 결과 $0.5 \%$ 까지 증가 할수록 균체의 성장이 왕성하였으나 그 이상의 농도에서는 균체 성장에 영향을 미치지 못하는 것으로 나타나 yeast extract의 최적 첨가 농도를 $0.5 \%$ 로 결정하였다(Fig. 6). Kim [10] 이 분리한 Baciilus sp. WRD-1은 질소원으로 yeast extract를 $1.0 \%$ 첨가했을 때 균의 생육이 가장 왕성하였다고 보고한 내 용과 비교할 때 질소원의 종류는 동일하지만 첨가농도는 다소 상이하였다.

\section{무기염의 영향}

무기염이 분리한 항균미생물인 B. licheniformis KJ-9의 생육

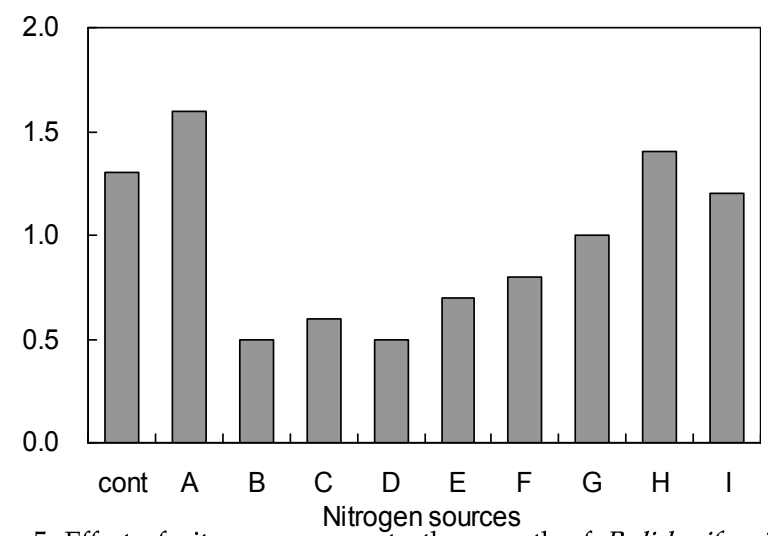

Fig. 5. Effect of nitrogen sources to the growth of $B$. licheniformis KJ-9. A, Yeast extract; B, $\mathrm{NH}_{4} \mathrm{NO}_{3} ; \mathrm{C},\left(\mathrm{NH}_{4}\right)_{2} \mathrm{HPO}_{4} ; \mathrm{D}$, $\mathrm{NH}_{4} \mathrm{Cl}$; E, Malt extract; $\mathrm{F}, \mathrm{NaNO}_{3}$; G, L-Asparagine; $\mathrm{H}$, Peptone; I, Beef extract

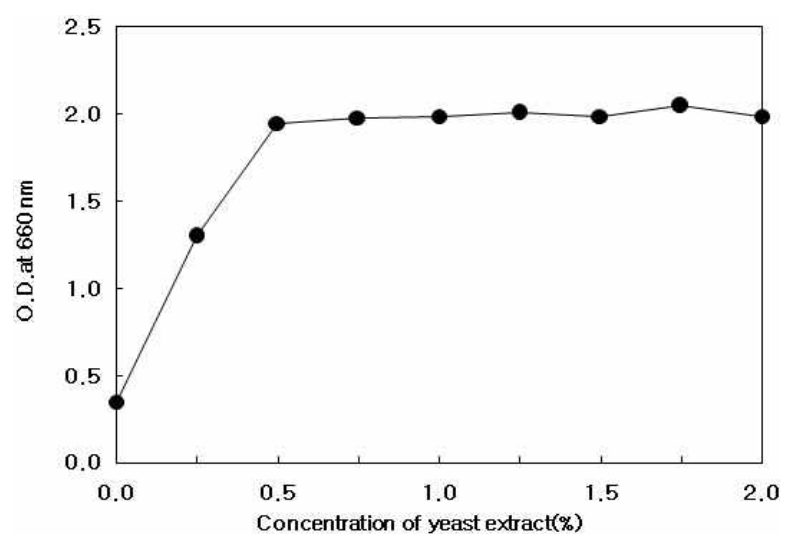

Fig. 6. Effect of concentration of yeast extract to the growth of B. licheniformis $\mathrm{KJ}-9$.
에 미치는 영향은 Fig. 7 과 같다. M9 minimal medium에 탄소 원은 $1.5 \%$ 의 soluble starch, 질소원은 yeast extract $0.5 \%$ 을 첨가하고 11 종류의 무기염 각각에 대한 영향을 검토한 결과 $\mathrm{CaCl}_{2}, \mathrm{NaCl}, \mathrm{MgSO}_{4} \cdot 7 \mathrm{H}_{2} \mathrm{O}, \mathrm{K}_{2} \mathrm{HPO}_{4}, \mathrm{MgSO}_{4} \cdot 7 \mathrm{H}_{2} \mathrm{O}$ 는 B. licheniformis KJ-9의 생육에 약간의 영향을 미쳤으나, $\mathrm{CoCl}_{2}$. $6 \mathrm{H}_{2} \mathrm{O}, \mathrm{ZnCl}_{2}, \mathrm{HgCl}_{2}, \mathrm{FeSO}_{4} \cdot 7 \mathrm{H}_{2} \mathrm{O}, \mathrm{AgNO}_{3}$ 과 같은 중금속 염은 B. licheniformis $\mathrm{KJ}-9$ 의 생육을 오히려 저해하는 것으로 나타나 최적 무기염은 $\mathrm{MgSO}_{4} \cdot 7 \mathrm{H}_{2} \mathrm{O} 0.05 \%$ 로 결정하였다.

\section{온도의 영향}

배양온도가 분리한 항균미생물인 B. licheniformis KJ-9의 생 육에 미치는 영향을 검토하여 Fig. 8에 나타내었다. 배양온도 를 $25 \sim 65^{\circ} \mathrm{C}$ 범위로 변화시키면서 배양한 결과 배양온도가 $25^{\circ} \mathrm{C}$ 에서 $30^{\circ} \mathrm{C}$ 로 높아짐에 따라 균체의 증식이 급격하게 이루 어졌으나 $35^{\circ} \mathrm{C}$ 에서 $55^{\circ} \mathrm{C}$ 까지는 서서히 증가하였다. 그러나 $60^{\circ} \mathrm{C}$ 이상에서는 B. licheniformis $\mathrm{KJ}-9$ 의 생육이 현저하게 저해 를 받아 생육이 늦은 것으로 나타나 생육 최적온도를 $50^{\circ} \mathrm{C}$ 로 결정하였다. Han 등[6]이 분리한 B. amyloliquefaciens 7079는

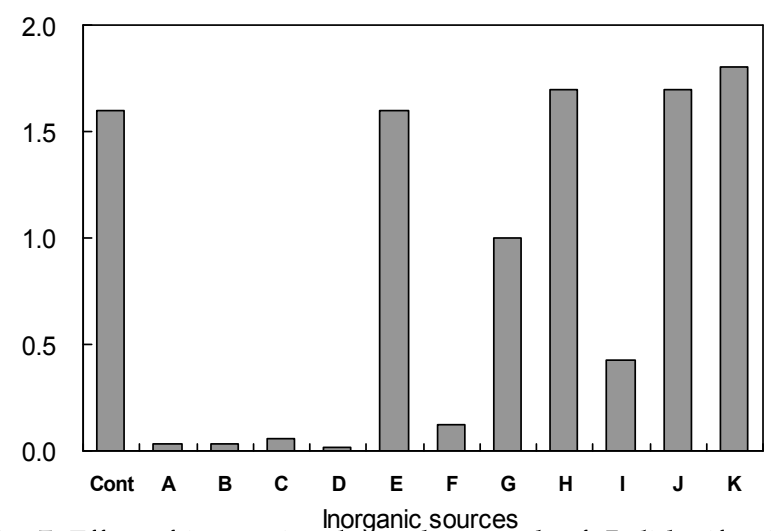

Fig. 7. Effect of inorganic salts to the growth of $B$. licheniformis KJ-9. A, $\mathrm{CoCl}_{2} \cdot 6 \mathrm{H}_{2} \mathrm{O} ; \mathrm{B}, \mathrm{ZnCl}_{2} ; \mathrm{C}, \mathrm{HgCl}_{2} ; \mathrm{D}, \mathrm{ZnSO}_{4}$. $7 \mathrm{H}_{2} \mathrm{O} ; \mathrm{E}, \mathrm{CaCl}_{2} ; \mathrm{F}, \mathrm{FeSO}_{4} \cdot 7 \mathrm{H}_{2} \mathrm{O} ; \mathrm{G}, \mathrm{MgCl}_{2} \cdot 6 \mathrm{H}_{2} \mathrm{O} ; \mathrm{H}$, $\mathrm{NaCl} ; \mathrm{I}, \mathrm{AgNO}_{3} ; \mathrm{J}, \mathrm{K}_{2} \mathrm{HPO}_{4} ; \mathrm{K}, \mathrm{MgSO}_{4} \cdot 7 \mathrm{H}_{2} \mathrm{O}$

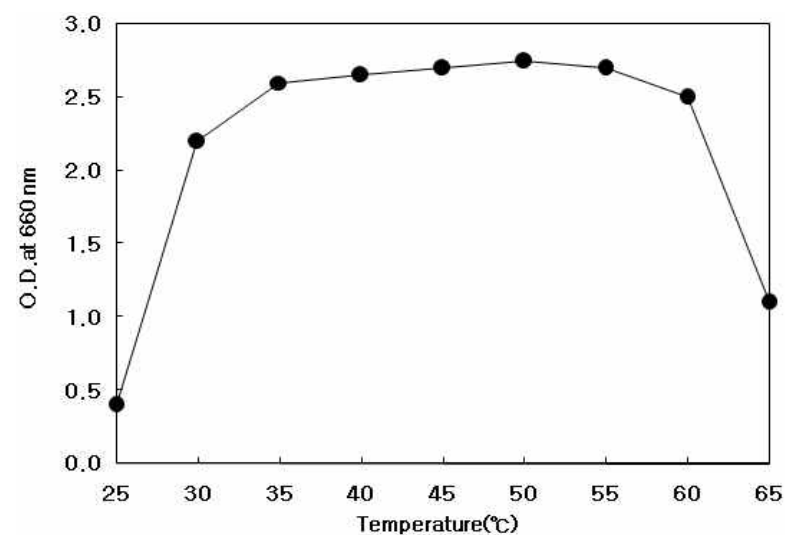

Fig. 8. Effect of temperature to the growth of B. licheniformis KJ-9. 
$30^{\circ} \mathrm{C}$ 에서 생육이 가장 활발하게 나타났고, $\mathrm{Kim}$ 등[11]이 분리 한 Bacillus sp. SS279는 $25 \sim 30^{\circ} \mathrm{C}$ 에서 최적온도를 나타낸 결과 보다는 상당히 높은 온도에서 생육이 가능하고 또한 생육가능 온도의 범위가 넓은 것으로 판단된다.

\section{초기 $\mathrm{pH}$ 영향}

초기 $\mathrm{pH}$ 가 항균미생물인 B. licheniformis $\mathrm{KJ}-9$ 의 생육에 미 치는 영향을 검토하여 Fig. 9에 나타내었다. pH 5.0 이하와 $\mathrm{pH} 10$ 이상에서는 생육이 급격히 떨어지는 현상을 보였으나 $\mathrm{pH} 5$ 에서 $\mathrm{pH} 10$ 까지는 생육이 왕성하여 거의 일정한 O.D. 값 을 나타내었다. 이상의 결과로 분리한 항균미생물인 B. licheniformis KJ-9의 생육가능 배지의 초기 $\mathrm{pH}$ 는 상당히 넓은 것으 로 생각되어 미생물의 배양 시 배지를 제조하였을 때 $\mathrm{pH}$ 를 조절하지 않은 $\mathrm{pH} 7.0$ 으로 결정하였다. 이와 같이 생육 $\mathrm{pH}$ 범 위가 넓은 것은 중성 경작지뿐만 아니라 약산성 경작지에서도 생육에 크게 영향을 받지 않을 것으로 추정되었다. Jung [8]은 배지의 초기 $\mathrm{pH}$ 를 $\mathrm{pH}$ 4 9까지 조정하여 최적 $\mathrm{pH}$ 를 조사한 결과 초기 $\mathrm{pH}$ 6과 $\mathrm{pH}$ 8사이에서 효소활성이 높게 나타나 최 적 $\mathrm{pH}$ 를 7로 보고하였고, Han 등[6]은 B. amyldiquefaciens 7079의 최적 $\mathrm{pH}$ 를 $\mathrm{pH}$ 6 7, Lee 등[15]은 Bacillus sp. HW-002 의 최적 $\mathrm{pH}$ 는 6.5 로 보고한 결과와 유사하였다.

\section{진탕 속도의 영향}

진탕 속도가 항균미생물인 B. licheniformis $\mathrm{KJ}-9$ 의 생육에 미 치는 영향을 검토하여 Fig. 10에 나타내었다. 배지의 초기 $\mathrm{pH}$ 는 배지를 제조하여 조절하지 않은 $\mathrm{pH} 7.0$ 으로 하고 $50^{\circ} \mathrm{C}$ 의 배양온도에서 진탕 속도를 100, 140, 180, $260 \mathrm{rpm}$ 으로 변화시 키면서 배양한 결과 진탕 속도를 증가 시킬수록 미생물의 증식 은 왕성하였다. 특히 $100 \mathrm{rpm}$ 에서 $180 \mathrm{rpm}$ 까지는 직선적으로 O.D.값이 증가하였으며 $180 \mathrm{rpm}$ 이상에서는 거의 일정한 값을 나타내었다. 이상의 결과로 B. licheniformis KJ-9의 배양을 위한 최적 진탕 속도는 $180 \mathrm{rpm}$ 으로 결정하였다. Kim [9]은 방선균 에 의한 Bacillus sp.에 유효한 항균물질 생산 보고에 서 진탕

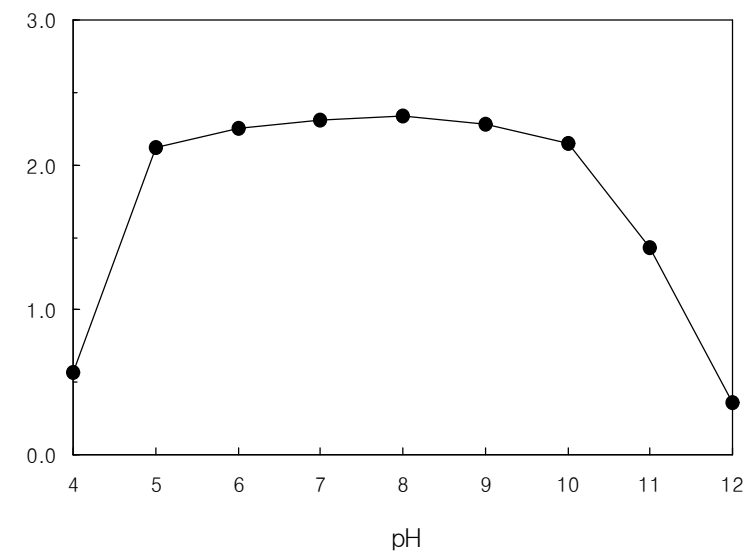

Fig. 9. Effect of $\mathrm{pH}$ to the growth of B. licheniformis KJ-9.

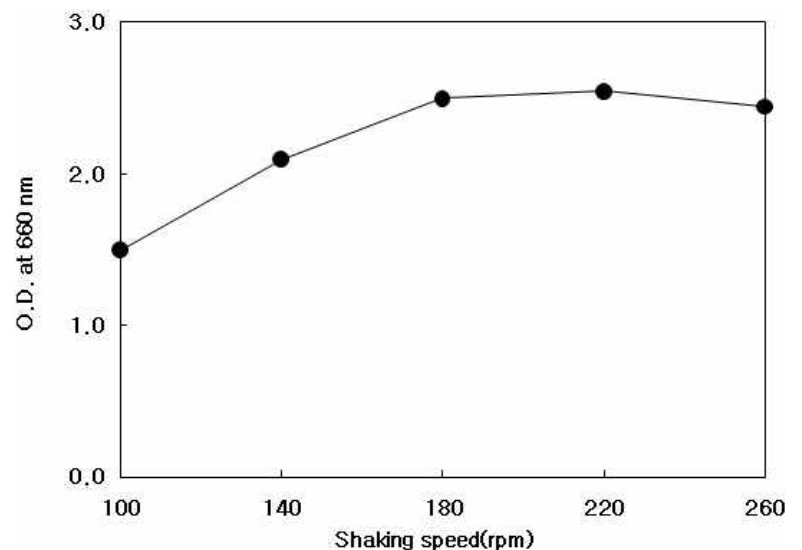

Fig. 10. Effect of shaking speed to the growth of B. licheniformis KJ-9.

속도를 $120 \mathrm{rpm}$ 으로 배양하였을 때 최고의 생산성을 나타내었 다는 보고보다는 조금 높은 진탕속도를 나타내었다.

\section{배양시간에 따른 항균활성}

이상의 최적 배양조건으로 분리한 B. licheniformis KJ-9를 배양할 때 배양시간이 항균물질의 생산에 미치는 영향을 검토 하여 Fig. 11에 나타내었다. 잿빛 곰팡이병을 유발하는 Botrytis cinerea에 대해서는 배양시간이 길어질수록 항균활성이 약간 씩 증가하여 배양 60 시간째의 시료에서 가장 높은 항균활성을 나타내었지만(Fig. 11A), 잎마름병의 원인균인 Corynespora cassicola, 시들음병을 유발하는 Fusarium oxysporum, 잘록병의

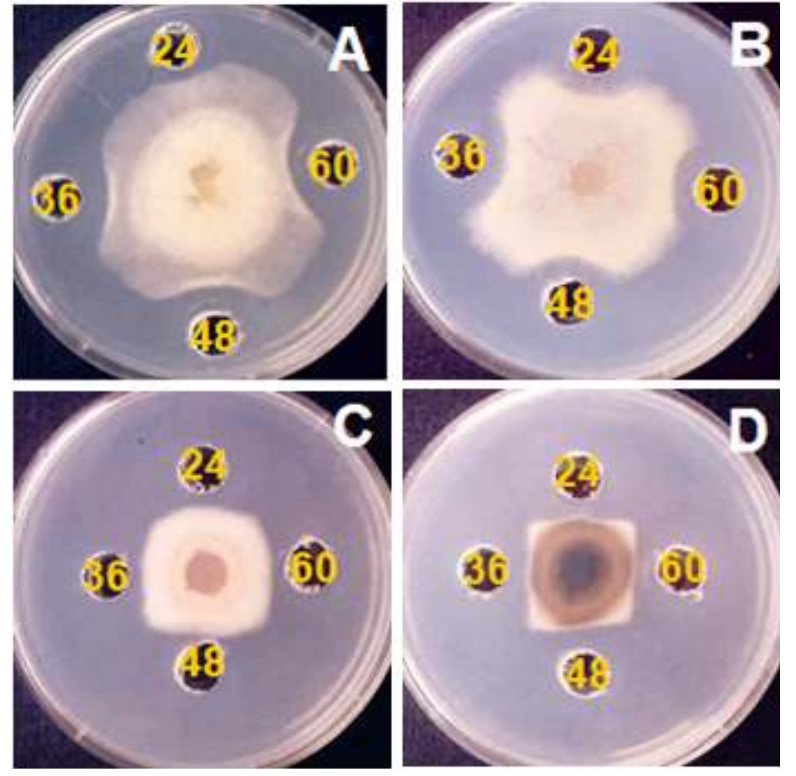

Fig. 11. Changes in antifungal activities of the supernatant of culture broth of $B$. licheniformis KJ-9 cultured at optimal liquid medium for $60 \mathrm{hr}$ against phytopathogenic fungi. A, Botrytis cinerea, B, Rhizoctonia solani; C, Fusarium oxysorum, D, Corynespora cassicola 
원인균인 Rhizoctonia solani의 식물병원성 균주에 대하여는 24 $\sim 60 \mathrm{hr}$ 째의 모든 시험구에서 거의 유사한 항균활성을 나타내 었다(Fig. 11B D). 결과는 나타내지 않았지만 배양 $12 \mathrm{hr}$ 째의 시료에서는 4 종류의 모든 병원성 균주에 대하여 아주 미약한 항균활성을 나타내었다. 이상의 결과로 본 연구에서 분리한 항균미생물을 이용한 기능성 퇴비생산 시에는 B. licheniformis $\mathrm{KJ}-9$ 를 $48 \sim 60 \mathrm{hr}$ 정도 배양하여 사용하는 것이 적당한 것으로 판단된다. Jung [8]이 분리한 Bacillus sp. P16는 $96 \mathrm{hr}$ 동안 배양한 결과 균의 생장은 $24 \mathrm{hr}$ 이후에 일정하게 유지되는 반면 효소활성은 $12 \mathrm{hr}$ 이후에 서서히 증가하였는데 본 논문 과 유사한 것으로 생각되었다. 이상의 연구결과를 종합해볼 때 항균활성이 우수한 B. licheniformis KJ-9는 톱밥 발효퇴비 생산뿐만 아니라 미생물제제 개발을 위한 깊이 있는 연구가 필요한 것으로 판단된다.

\section{감사의 글}

본 연구는 2009년도 진주산업대학교 학술연구조성비 지원 에 의해 수행된 연구결과의 일부이며 이에 감사드립니다.

\section{References}

1. Anson, M. L. 1939. The estimation of pepsin, trypsin, papain and cathepsin with hemoglobin. J. Gen. Physiol. 22, 79-85.

2. Arima, K. H., M. Imanaka, K. A. Fukuta, and G. Tamura. 1964. Pyrrolnitrin, a new antibiotic substance, produced by Pseudomonas. Agric. Biol. Chem 28, 575-576.

3. Brian, P. W., J. M. Wright, J. Stunns, and A. M. Way. 1951. Uptake of antibiotic metabolites of soil microorganisms by plant. Nature. 167, 347-349.

4. Gregory, K. F., O. N. Allen, A. J. Riker, and W. H. Peterson. 1952. Antibiotics as agents for the control of certain damping-off fungi. Am J. Botany. 9, 405-415.

5. Han, K. H. and S. D. Kim. 1999. Selection and identification of Promicromonospora sp. KH-28 producing chitinase and antifungal antibiotic. Kor. J. Appl. Microbiol. Biotechnol. 27, 191-196.

6. Han, O. K., E. T. Lee, and S. D. Kim. 2001. Chitinase of multifunctional antagonistic bacterium Bacillus amyloliquefaciens 7079 against phytophathogenic fungi. Kor. J. Appl. Microbiol. Biotechnol., 29, 142-148.

7. Holt, J. G., N. R. Krieg, P. H. A. Sneath, J. T. Staley, and S. T. Wiliilams. 1994. Bergey's mannual of determinative bacteriology. 9th. Wiliilams willkins.

8. Jung, M. R. 1997. Isolation and characterization of Bacillus sp. producing chitosanase. Chonnam National University. M. S. Thesis.

9. Kim, J. H. 2000. Production of an antibiotic effective for Bacillus sp. Konkuk University. M. S. Thesis.

10. Kim, J. W. 2001. Growth effect of tomato treated with Bacillus sp. WDR-1 cultures. Dong-A University. Ph. D.
Thesis.

11. Kim, S. S., G. J. Joo, J. Y. Uhm, Y. J. Kim, and I. K. Lee. 1997. Antifungal Activity of Bacillus sp. SS279 and Biocontrol of Apple White Rot Fungus, Botryospaeria dothidea. Kor. J. Appl. Microbiol. Biotechnol., 25, 527-536.

12. Ko, Y. H. 1982. Study on the antifungal antibiotics produced by a strain of the genus Streptomyces sp. Ph. D. Thesis, Seoul National University, Seoul, Korea.

13. Lee, D. S., H. Kim, and M. Y. Park. 1984. Combination of colony formation and congo red reaction for detecting intraand extra- cellular cellulolytic activities. Kor. J. Appl. Microbiol. Bioeng. 12, 305-309.

14. Lee, E. T. and S. D. Kim. 1999. Isolation and antifungal activity of the chitinase producing bacterium Serratia sp. 3095 as Antagonistic Bacterium against Fusarium sp. Agric. Chem Biothechnol. 42, 181-187.

15. Lee, H. W., J. W. Choi, D. P. Han, N. W. Lee, S. L. Park, and D. H. Yi. 1996. Identification and production of constitutive chitosanase from Bacillus sp. HW-002. J. Microbiology and Biotechmology 6, 12-18.

16. Leger, S. R. J., R. M. Cooper, and A. K. Charmley. 1986. Cuticle-degrading enzymes of entomopathogenic fungi: regulation of production of chitinolytic enzymes. J. Gen. Microbiol. 132, 1509-1517.

17. Leoffler, W. J., S. M. Tschen, N. Vanittanakom, M. Kugler, E. Knorpp, T. F. Hsieh, and T. G. Wu. 1986. Antifungal effects of bacilysin and fengymycin from Bacillus subtilis F-29-3: a comparison with activaties of other Bacillus antibiotics. J. Phytopathol. 115, 204-213.

18. Mitchell, J. W., W. J. Zaumeter, and W. P. Anderson. 1952. Translocation of streptomycin in bean plant and its effect on bacterial blights. Science. 115, 114-115.

19. Paulitz, T. C. and J. E. Loper. 1991. Lack of a role for fluorescent siderophore production in the biological control of Phythium damping-off cucumber by a strain of Pseudomonas putida. Phytopathol. 81, 930-935.

20. Ru, M. G. 2003. Cloning and characterization of a gene for fibrinolytic enzyme from Bacillus subtilis A1. Jinju National University. M. S. Thesis.

21. Schiewe, A. and K. Mendgen. 1992. Identification of antagonists for biological control of the post harvest pathogen Pezicula malicorticis and nectria galligena on apple. Phytopathology 134, 229-237.

22. Siegelm, M. and H. D. Sisker. 1977. Antifungal compounds Vol 2. Interactions in Ecological System 227.

23. Sneath, P. H. A., N. S. Mair, M. E. Sharpe, and J. G. Holt. 1984. Bergey's manual of systematic bacteriology, Vol. 2, 104-1207. Wiliilams and Willkins Press, New York.

24. Takeuchi, S., K. Hirayama, K. Ueda, H. Sasaki, and H. Yonehara. 1958. Blasticidin S, a new antibiotic. J. Antibiot. 11, 1-5.

25. Yun, K. H., E. T. Lee, and S. D. Kim. 2001. Identification and antifungal antagonism of Chryseomonas luteola 5042 against Phytophthora capsici. Kor. J. Appl. Microbiol. Biotechnol. 29, 186-193. 
초록 : 토양으로부터 분리한 Bacillus licheniformis KJ 9 의 특성

서동철 ${ }^{1}$ 고정애 · 갈상완 $\cdot$ 이상원*

(진주산업대학교 미생물공학과, ${ }^{1}$ 경상대학교 농업생명과학원)

고품질의 발효퇴비를 생산할 목적으로 자연계로부터 효소활성이 높고 식물병원성 균주에 대한 항균활성이 우 수한 미생물을 순수분리 하여 배양학적 특성을 검토하였다. 부엽토 등으로부터 CMCase, protease 및 chitinase 활성이 높고 식물병원성 균주에 대하여 항균활성이 우수한 KJ-9균주를 분리한 다음 형태학적 및 생화학적 특성을 검토하고 Bergey's Mannual of Systematic Bacteriology의 방법과 ATB (Automated Identification) computer system (Bio Merieux, France)을 이용한 API 50 CHL Carbohydrate Test Kit(Bio Merieux, France)를 통하여 동정한 결과 Bacillus licheniformis로 밝혀졌다. B. licheniformis KJ-9의 최적배지 성분을 검토한 결과 탄소원은 $1.5 \%$ soluble starch, 질소원은 $0.5 \%$ yeast extract, 무기염은 $0.05 \% \mathrm{MgSO}_{4} \cdot 7 \mathrm{H}_{2} \mathrm{O}$ 이었으며, 배지의 초기 $\mathrm{pH}$ 는 7.0 , 배양온도는 $50^{\circ} \mathrm{C}$ 그리고 진탕속도는 $180 \mathrm{rpm}$ 으로 밝혀졌다. 최적배양 조건으로 B. licheniformis KJ-9를 배양하였을 때 36 60 $\mathrm{hr}$ 째의 배양액은 잿빛 곰팡이병을 유발하는 Botrytis cinerea, 잎마름병의 원인균인 Corynespora cassicola, 시들음병 을 유발하는 Fusarium oxysporum, 잘록병의 원인균인 Rhizoctonia solani의 식물병원성 미생물 균사생장을 효과적 으로 억제하였다. 